\title{
Physical and Mechanical Properties of Composites Made with Aluminous Cement and Basalt Fibers Developed for High Temperature Application
}

\author{
Pavel Reiterman, ${ }^{1,2}$ Ondřej Holčapek, ${ }^{1}$ Marcel Jogl, ${ }^{1}$ and Petr Konvalinka' \\ ${ }^{1}$ Experimental Centre, Faculty of Civil Engineering, Czech Technical University in Prague, Thákurova 7, \\ 16629 Prague 6, Czech Republic \\ ${ }^{2}$ University Centre for Energy Efficient Buildings, Czech Technical University in Prague, Třinecká 1024, \\ 27343 Bustehrad, Czech Republic
}

Correspondence should be addressed to Pavel Reiterman; pavel.reiterman@fsv.cvut.cz

Received 2 March 2015; Revised 28 April 2015; Accepted 11 May 2015

Academic Editor: Antônio G. B. de Lima

Copyright (C) 2015 Pavel Reiterman et al. This is an open access article distributed under the Creative Commons Attribution License, which permits unrestricted use, distribution, and reproduction in any medium, provided the original work is properly cited.

\begin{abstract}
Present paper deals with the experimental study of the composition of refractory fiber-reinforced aluminous cement based composites and its response to gradual thermal loading. Basalt fibers were applied in doses of $0.25,0.5,1.0,2.0$, and $4.0 \%$ in volume. Simultaneously, binder system based on the aluminous cement was modified by fine ground ceramic powder originated from the accurate ceramic blocks production. Ceramic powder was dosed as partial replacement of used cement of 5, 10, 15, 20, and 25\%. Influence of composition changes was evaluated by the results of physical and mechanical testing; compressive strength, flexural strength, bulk density, and fracture energy were determined on the different levels of temperature loading. Increased dose of basalt fibers allows reaching expected higher values of fracture energy, but with respect to results of compressive and flexural strength determination as an optimal rate of basalt fibers dose was considered $0.25 \%$ in volume. Fine ground ceramic powder application led to extensive increase of residual mechanical parameters just up to replacement of $10 \%$. Higher replacement of aluminous cement reduced final values of bulk density but kept mechanical properties on the level of mixtures without aluminous cement replacement.
\end{abstract}

\section{Introduction}

The main aim of current technology is the development of new type of composites which are made to measure to required conditions. A common problem of new types of structures made from high performance materials is their behaviour in certain specific conditions and situations. Typical example of such specific situation is fire; lack of fire resistance can be expected especially in case of very subtle concrete structures.

Concrete undergoes sequences of structural changes by actual thermal load level. First phase is the evacuation of physically bonded water taking place up to $200^{\circ} \mathrm{C}$. Low permeability of high performance concrete (HPC) causes internal stresses incurred by accumulated steam.
Sudden escape of steam is often reason of surface spalling of high performance concrete (HPC). The behaviour of concrete surface layer of HPC with special consideration to spalling was described in $[1,2]$. This deficiency is necessary to be solved by another additional protection in the form of fire tiling or other kind of arrangement.

For Portland cement based concrete and other composites the reaching of thermal load of $400^{\circ} \mathrm{C}$ is significant, when important product of hydration, $\mathrm{Ca}(\mathrm{OH})_{2}$-portlandite, decomposes to quick lime and $\mathrm{CO}_{2}$. Origin of lime during temperature loading or some fire accident could be source of secondary internal stresses because of lime hydration. That has an extensive sense of inconvenience of limestone application as aggregate as well as fine ground additive to high temperature resistance concrete. Another undesirable 
volume changes are attendant exhibition of quartz transformation after exceeding thermal rate of $573^{\circ} \mathrm{C}$. Crack formation caused by the above mentioned changing usually has devastating effect on traditional concrete because of usually high volume of quartz in the mixture. Residual mechanical parameters are achieving about $15 \%$ of original values which is notably bellow designed requirements [3]. To reach sufficient resistance to high temperature of composites is necessary to include into the composition design properties of all components, as described.

In connection to thermal loading was highlighted expansion caused by structural transformation of $\mathrm{SiO}_{2}$ and cement hydrates because of its strong destructive effect. But the initial part of thermal loading of cement based composites is affected by contraction, due to water escaping, which increases gradient of total volume changes. Observable evidence of tensile strength exceeding is crack formation. Usually, different types of fibers are applied to reduce undesirable internal tension in concrete mixture. To improve fire resistance of concrete authors in [4] studied the possible application of PVA fibers on concrete and its residual strength after exposure to $600^{\circ} \mathrm{C}$. Combustible fibers contribute to increased fire resistance only by creating escaping channels for steam after their burning out [5]. Steel fibers are often used for tunnel lining to improve spalling resistance, which is, in case of such structures required, to protect bar reinforcement, but recrystallization of steel limits their application on higher temperatures than $600^{\circ} \mathrm{C}$ and cannot ensure their permanent parameters.

Development of fire barriers, which are based on aluminous cement, has become an integral part of building industry, especially with regard to the current global political and security situation. Aluminous cement has excellent characteristics in relation to the high temperatures in comparison to traditional Portland cement. But fundamental problem of aluminous cement production is its increased energy consumption. Production temperature of aluminous cement is higher than of commonly used Portland clinker.

To reduce negative environmental impact of cement production there are very often applied several types of additives for traditional structural concrete, such as fly ash, silica fume, ground limestone, and ground blast furnace slag. Unsufficient chemical properties of these mineral additives fundamentally limit their application on composites loaded to high temperature. Cement replacement by fine ground ceramic powder (FGCP) could be an interesting solution for refractory composites development, although reaction mechanism is fundamentally different than in case of Portland cement hydration. FGCP is generated during ceramic production as waste material without any other practical utilization yet.

Ratio of aggregate in traditional structural concrete is about $85 \%$ of concrete volume [6]. Refractory composites are usually formulated as fine grain concrete mixtures with relatively high dose of aluminous cement which is necessary assumption of good resistance to high temperature [7]. Common dose of aluminous cement for refractory composites is about $30 \%$ in volume which well document their economical and energy consumption. Higher ratio of fine compounds in concrete mixture allows the good space distribution of used fibers [8]. But for their efficient and full employment to reach the adequate anchoring is important.

Basalt Fibers. Fundamental advance of nonmetal fibers production began during fifties of the twentieth century with development of aviation and according to special requirements of army $[9,10]$. Natural basalt is the worldwide spread material of volcanic origin, primarily resistant to corrosion in acid and also in alkaline environment, and is characterized by excellent resistance to high and low temperatures from $-260^{\circ} \mathrm{C}$ to $+750^{\circ} \mathrm{C}$. An additional advantage of basalt is its high hardness ( 8.5 by Mohs), which greatly affects the increase in concrete resistance to abrasion. Basalt tiles are indispensable part of numbers of pieces of technology equipment in chemical and metallurgical industry. Igneous rocks as basalt have a sufficient melting temperature, just about 1500$1700^{\circ} \mathrm{C}$, which allows their great industry application in form of fibers $[8,11]$.

Basalt is consisting of number of oxides with essential impact on its final properties. Dominant $\mathrm{SiO}_{2}$ is represented by $43.3-47.0 \%$ of weight, content of $\mathrm{Al}_{2} \mathrm{O}_{3}$ is just about $11.0-13.0 \%, \mathrm{CaO}$ and $\mathrm{MgO}$ are both represented in case of basalts of common chemical composition by $8.0-12.0 \%$, and other oxides form just up to $5 \%$ of weight $[12,13]$. Chemical properties, especially content of $\mathrm{SiO}_{2}$, influence the possibility of processing to fibers. Recommended limit up to $46 \% \mathrm{SiO}_{2}$ could ensure good workability of melted mixture without undesirable crystallization during hardening [14].

Basalt fibers are predominantly produced in form of continual fiber which is cut to required length. Intensive development of basalt fibers in form of textiles, bars, roving, and so forth is also caused by the absence of health risks when compared to toxic asbestos fibers [15]. With respect to current requirements for building materials the low price of basalt fibers when compared to glass or steel fibers is interesting. Substance of present fact lies in quite easy production process where it is not necessary to add other additives or admixtures or any necessary surface treatment $[16,17]$. High dose of fibers reduces workability of fresh mixture [18].

Resistance to high temperatures, alkali-resistance, and extremely low absorbability allow wide application of basalt fibers on building industry and technical practise. Longterm durability of basalt fibers and excellent mechanical and shielding properties enable their application on nuclear plants structures $[19,20]$.

Generally, basalts contribute to improved properties of concrete because of similar physical properties as traditional aggregates, for example, bulk density [21]. Optimal and effective dose of basalt fibers for fine grained concrete is about $0.5 \%$ in volume. The use of 1 to $2 \%$ of the fiber volume may be beneficial in structural application where there is a requirement of high energy absorption capability, improved resistance against delamination, spalling and fatigue, modulus of rupture, impact resistance, and the fracture toughness of the concrete [22].

Aluminous Cement. High alumina cement contains the principal hydraulic minerals such as CA (calcium aluminate) and 
$\mathrm{CA}_{2}$ (calcium aluminate). History of high aluminous cement production started in the twenties of the 20th century. Rapid evolution of initial mechanical parameters was convenient for postwar requirements of building industry at the time which was focused on the restoration of infrastructure. Hydration of aluminous cement could be expressed by the following equations (1) and (2) by using traditional cement chemistry nomenclature $\left(\mathrm{C}=\mathrm{CaO} ; \mathrm{S}=\mathrm{SiO}_{2} ; \mathrm{H}=\mathrm{H}_{2} \mathrm{O} ; \mathrm{A}=\mathrm{Al}_{2} \mathrm{O}_{3}\right)$ :

$$
\begin{gathered}
\mathrm{CA}+10 \mathrm{H} \longrightarrow \mathrm{CAH}_{10} \\
2 \mathrm{CA}+11 \mathrm{H} \longrightarrow \mathrm{C}_{2} \mathrm{AH}_{8}+\mathrm{AH}_{3}
\end{gathered}
$$

Hydrated high aluminous cement proves having sufficient resistance to chemical corrosion compared with Portland cement, because of absence of portlandite. Progress of hydration process of high aluminous cement is closely affected by temperature [23]. Unfortunately, increased curing temperatures lead to metastable hydrates formation.

Several collapses of load bearing structures made from aluminous cement in the seventies and eighties intensified the scientific research of aluminous cement hydration products and their long-term properties. Common problem of aluminous cement lies in the risk of subsequent conversion of hydration products and decrease of composite mechanical parameters when temperature of hardening mixture exceeds just about $35^{\circ} \mathrm{C}$. Conversion of metastable hydrates is expressed by

$$
\begin{aligned}
& 3 \mathrm{CAH}_{10} \longrightarrow \mathrm{C}_{3} \mathrm{AH}_{6}+2 \mathrm{AH}_{3}+18 \mathrm{H} \\
& 3 \mathrm{C}_{2} \mathrm{AH}_{8} \longrightarrow 2 \mathrm{C}_{3} \mathrm{AH}_{6}+\mathrm{AH}_{3}+9 \mathrm{H}
\end{aligned}
$$

The core of the converse is the recrystallization of hexagonal $\mathrm{C}_{3} \mathrm{AH}_{6}$ to its cubic form with higher specific density. Increasing of binder porosity then leads to loss of integrity of such concrete and to gradual decreasing of mechanical parameters. It should be noted that structural aluminous cement concrete has been prohibited because of the risk of the above described conversion and weakening that can take place under certain temperature/humidity conditions [23, 24]. Conversion of aluminous cement and loss of mechanical properties are usually accompanied by visual changes when binding part of such concrete turns to red [25].

The binder and its hydration product significantly control final properties, behavior, and thermal resistance of composite; in particular the contact zone between hydration products and surface of aggregates and fibers is of importance [26]. Despite restriction of aluminous cement for structural elements production, it stays to be an extremely important material for refractories development. Final resistance to high temperature of hydrated aluminous cement is determined by the content of $\mathrm{Al}_{2} \mathrm{O}_{3}$. Secar $71\left(70 \%\right.$ of $\left.\mathrm{Al}_{2} \mathrm{O}_{3}\right)$ was used because performed temperature loading exceeded $1000^{\circ} \mathrm{C}$.

Fine Ground Ceramic Powder (FGCP). Nowadays question of the influence of construction on quality of environment is often discussed. Therefore a number of laboratories are looking for solution of increasing negative impact closely associated with cement and concrete production.
Attention of a number of research organizations is focused on the development of alternative binder systems and other substituents of cement in concrete.

Actual decline of heavy industry, as a producer of majority of commonly used additives such as fly ash, silica fume, and ground blast furnace slag, is an essential problem because of lack of additives with suitable chemical compositions. One of the possibilities is using of fine ceramic powder generated from the manufacture of accurate brick blocks [27]. This waste material has pozzolanic properties as is confirmed by many of the buildings of ancient Rome [28, 29].

Very important role in performance of concrete in severe environment is played by character of pore system. Influence of ceramic powder was studied in [30] to evaluate its utilisation in the lime based plasters, where positive impact on thermal properties was confirmed.

Generally, pozzolanic additives retard initial evolution of mechanical properties but they provide very interesting values of long-term properties in relation to durability; predominantly in concrete technology is further application of various pozzolanic additive solutions to ensure suitable rheology, mechanical parameters, and durability properties presented by frost and chemical resistance [31].

Efficiency of each mineral additive is influenced by its granularity and shape of particles. Often disadvantage of some mineral additives lies in the granularity and high specific surface because of decreasing rheological properties of fresh paste.

It is important to note that mechanism of hydration of aluminous cement is different when compared to traditional Portland cement as well as role of mineral additives in studied binder system with absence of $\mathrm{Ca}(\mathrm{OH})_{2}$. Hydration of aluminous cement in presence of reactive siliceous additives is marked by the formation of stratlingite in AFm phase closely related to $\mathrm{C}_{2} \mathrm{AH}_{8}$ [23]. Theoretically, stratlingite could be formed in the system $\mathrm{CaO}-\mathrm{SiO}_{2}-\mathrm{Al}_{2} \mathrm{O}_{3}-\mathrm{H}_{2} \mathrm{O}$ according to (5)

$$
\mathrm{C}_{2} \mathrm{AS}+8 \mathrm{H} \longrightarrow \mathrm{C}_{2} \mathrm{ASH}_{8}
$$

Detailed description of aluminous cement hydration in presence of siliceous components was researched in $[32,33]$. Some research works were focused on study of various siliceous additives [34-36] in aluminous cement, but application of FGCP is novel. Retarding of initial mechanical parameters and reduction of hydration heat can be concluded from similar focused research works. Formation of stratlingite has a high importance because of its stability in ambient condition and good cementing properties [37] which ensures long-term durability [38].

The objective of this paper was to develop aluminous cement based composite for high temperature application. Undesirable environmental impact related to aluminous cement production was reduced by partial replacement by FGCP. Secondary beneficial effect of FGCP application lies in positive influence on processes of hydration and formation of stable C-A-S-H hydrates. Prevention of conversion of metastable hydrates of pure aluminous cement is an essential problem of this binder system. Basalt fibers were applied 
to ensure suitable ductility and mechanical properties of designed composite.

\section{Materials and Methods}

2.1. Mixture Design. FGCP was used as replacement of aluminous cement gradually up to $25 \%$. However, process of hydration of aluminous cement in presence of siliceous components is highly dependent on actual chemical composition and physical properties of binder components; specific surface $\left(\mathrm{m}^{2} \cdot \mathrm{kg}^{-1}\right)$ and chemical analysis were determined.

Experimental program was focused on the study of basic physical, mechanical, and fracture properties of refractory composites with ceramic powder replacement and with different amount of basalt fibers $(0.25 \%, 0.5 \%, 1.0 \%, 2.0 \%$, and $4.0 \%)$.

Application of efficient plasticizer is necessary to preserve good workability and low rate of water-cement ratio. Polycarboxylate plasticizer was used in dose of $2.5 \%$ of binder based on previous research. Negative impact of mentioned organic compound even its flammability was not confirmed [39].

Fine crushed basalt aggregates of two fractions, $0-4 \mathrm{~mm}$ and $2-5 \mathrm{~mm}$, were designed into the composite composition because their absence could reduce final mechanical properties. Application of natural aggregates significantly contributes to the economic aspects of composite materials. Particle size distribution of used basalt aggregates and FGCP was investigated by using EU standard system of sieves. Present design of fine grain composites makes varied dose of basalt fibers possible, including relatively high dose.

Dose of basalt fibers of length $12 \mathrm{~mm}$ was gradually increased in the logarithmical sets from the minimum of 0.25 just up to $4.0 \%$ of mixture volume. This reinforcing was applied for each modification of binder by FGCP. Detailed composition of all studied composites is shown in Table 1. Sets of prismatic specimens of dimensions $40 \times 40 \times 160 \mathrm{~mm}^{3}$ were produced for following testing.

2.2. Temperature Loading. Gradual temperature loading was performed in the automatic electric furnace at the $10^{\circ} \mathrm{C} / \mathrm{min}$ heating rate. After reaching required level $\left(600^{\circ} \mathrm{C}\right.$ or $\left.1000^{\circ} \mathrm{C}\right)$ samples were after other three hours spontaneously cooled down. Figure 1 clearly describes whole temperature loading process in time. Reference specimens to thermal loaded ones were dried at $105^{\circ} \mathrm{C}$ for 24 hours (to evaporate free water from inner pore structure) before testing.

2.3. Investigated Parameters. The investigated parameters were determined on dried samples at $105^{\circ} \mathrm{C}$ and then after thermal loading $\left(600^{\circ} \mathrm{C}\right.$ and $\left.1000^{\circ} \mathrm{C}\right)$. Bulk density of studied composites was investigated on the base of the actual weight and accurate dimensions of specimens. Changes of bulk density are related to structural transformation and mineralogical changes during heating [31].

All tests of mechanical properties were carried out according to the standard CSN EN 196-1 [40] on prismatic specimens $40 \times 40 \times 160 \mathrm{~mm}^{3}$. Flexural strength $f_{\text {tm }}$ measurement was organized as a three-point test with

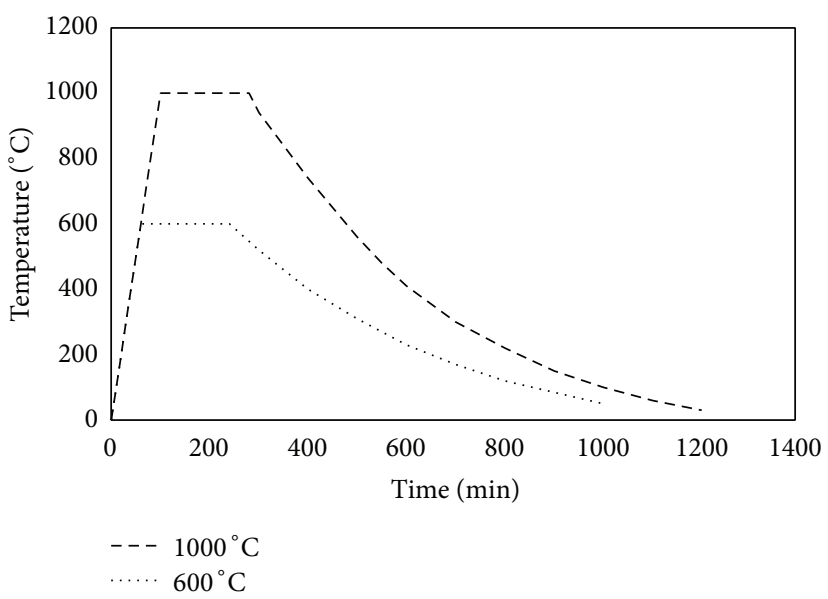

FIgURE 1: Temperature loading scheme.

supports distance of $100 \mathrm{~mm}$ and was calculated by help of the maximum reached force. Because of determination of fracture energy specimens were equipped with notch of just $15 \mathrm{~mm}$ depth. For this testing we used universal loading machine MTS 100 allowing us to control experiment by the deformation speed which was set up to $0.2 \mathrm{~mm} / \mathrm{min}$.

The compressive strength $\left(f_{\mathrm{cm}}\right)$ test was performed on two fragments left after flexural test. The area under compressive load $\left(40 \times 40 \mathrm{~mm}^{2}\right)$ has been demarcated by the loading device. From the numerical output of flexural test values of fracture energy $G_{f}\left(\mathrm{~J} \cdot \mathrm{m}^{-2}\right)$ were finally calculated as a property suitable to evaluate flexural behaviour of fiberreinforced composites because of exactly expressed work $(\mathrm{J})$ necessary to break tested cross section [41], highlighted area at Figure 2. For the determination of fracture energy RILEM recommendation (6) was used [42]. Each set of specimens was presented by just three pieces except for compressive strength $f_{\mathrm{cm}}$ which is average from six performed measurings:

$$
G_{f}=\frac{1}{a \cdot(b-n)} \int_{0}^{\delta_{\max }} F(\delta) d \delta
$$

$G_{f}:$ fracture energy $\left(\mathrm{J} \cdot \mathrm{m}^{-2}\right), F$ : force $(\mathrm{N}), \delta$ : deflection $(\mathrm{mm})$, $a$ : width $(\mathrm{m}), b$ : height $(\mathrm{m})$, and $n$ : depth of notch $(\mathrm{m})$.

\section{Results and Discussion}

Detailed chemical composition of used aluminous cement and applied FGCP is shown in Table 2, as well as values of specific surface. High fineness of studied cement supplementary material determines its suitable reactivity.

Particle size distribution of used basalt aggregates and FGCP is shown in Figure 3. Grading of basalt aggregates presents optimal composition. FGCP contains relatively high amount of coarser particles which is documented by the sieve test. Just about $70 \%$ of grains of FGCP are smaller than $0.125 \mathrm{~mm}$.

The values presented in Table 3 are means from three samples (except for compressive strength $f_{\mathrm{cm}}$ which is 
TABLE 1: Composition of studied composites.

\begin{tabular}{|c|c|c|c|c|c|c|c|c|c|c|c|}
\hline \multicolumn{6}{|c|}{ Basalt fibers (\%) } & \multicolumn{2}{|c|}{ Basalt aggregates $\left(\mathrm{kg} \cdot \mathrm{m}^{-3}\right)$} & \multicolumn{2}{|c|}{ Fine components $\left(\mathrm{kg} \cdot \mathrm{m}^{-3}\right)$} & \multicolumn{2}{|c|}{ Liquids $\left(\mathrm{kg} \cdot \mathrm{m}^{-3}\right)$} \\
\hline $0.0 \%$ & $0.25 \%$ & $0.5 \%$ & $1.0 \%$ & $2.0 \%$ & $4.0 \%$ & & & & & & \\
\hline $\begin{array}{l}0 \\
(\mathrm{~kg})\end{array}$ & $\begin{array}{l}7.25 \\
(\mathrm{~kg})\end{array}$ & $\begin{array}{l}14.5 \\
(\mathrm{~kg})\end{array}$ & $\begin{array}{l}29.0 \\
(\mathrm{~kg})\end{array}$ & $\begin{array}{l}58.0 \\
(\mathrm{~kg})\end{array}$ & $\begin{array}{l}116.0 \\
(\mathrm{~kg})\end{array}$ & $0 / 4 \mathrm{~mm}$ & $2 / 5 \mathrm{~mm}$ & Cement Secar 71 & FGCP & Water & Plasticizer Sika 1035 \\
\hline $\mathrm{R}-0$ & A-0 & B-0 & $\mathrm{C}-0$ & D-0 & $\mathrm{E}-0$ & 880 & 220 & 900 & 0 & 224 & 22.75 \\
\hline R-5 & A-5 & B-5 & C-5 & D-5 & E-5 & 880 & 220 & 855 & 45 & 224 & 22.75 \\
\hline $\mathrm{R}-10$ & A-10 & B-10 & $\mathrm{C}-10$ & $\mathrm{D}-10$ & $\mathrm{E}-10$ & 880 & 220 & 810 & 90 & 224 & 22.75 \\
\hline $\mathrm{R}-15$ & A-15 & B-15 & C-15 & $\mathrm{D}-15$ & E-15 & 880 & 220 & 765 & 135 & 224 & 22.75 \\
\hline $\mathrm{R}-20$ & A- 20 & B-20 & $\mathrm{C}-20$ & D-20 & E-20 & 880 & 220 & 720 & 180 & 224 & 22.75 \\
\hline R-25 & A-20 & B- 25 & C-25 & D-25 & E-25 & 880 & 220 & 675 & 225 & 224 & 22.75 \\
\hline
\end{tabular}

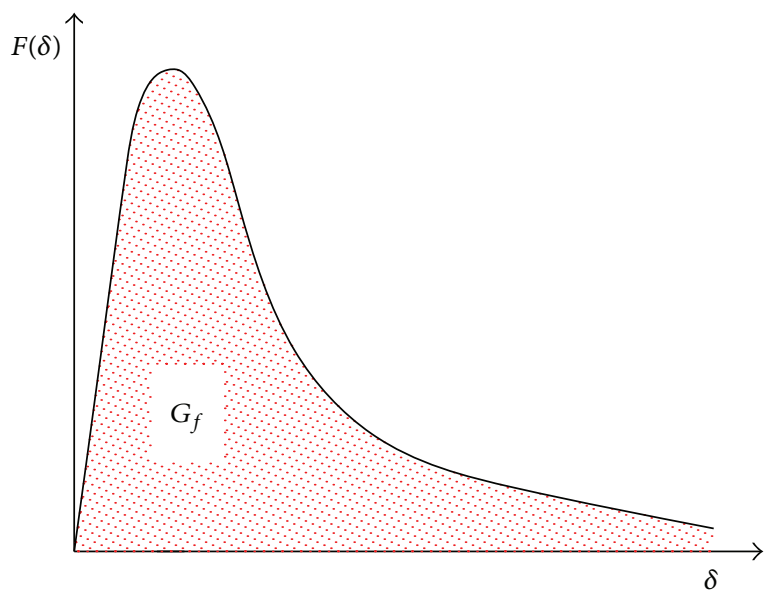

FIGURE 2: Expression of fracture energy.

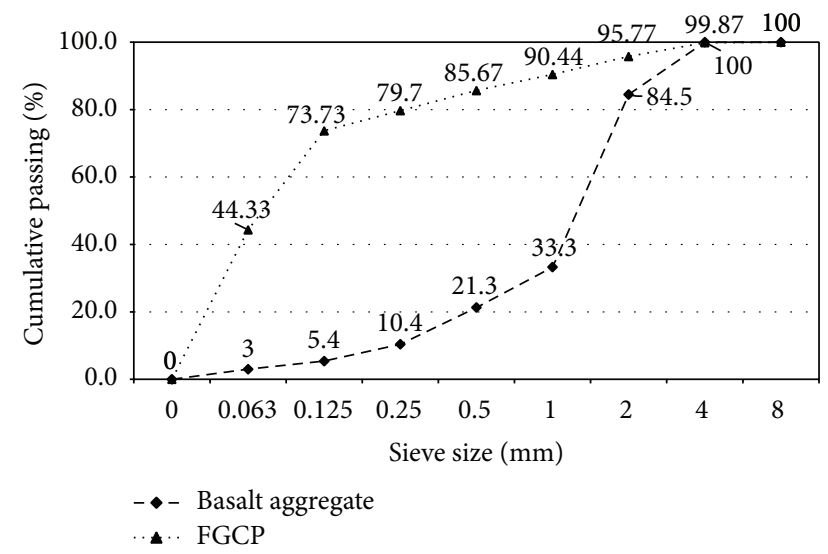

FIGURE 3: Granularity of used fine grounded ceramic powder and used basalt aggregate.

average from six performed tests) which were loaded up to two high temperature levels. Reference set of specimens were dried to $105^{\circ} \mathrm{C}$ to equilibrium weight to limit negative impact of the steam evacuating during the heating process, which could cause undesirable spalling and cracks formation. Then intended samples were heated up to $600^{\circ} \mathrm{C}$ and $1000^{\circ} \mathrm{C}$.
TABLE 2: Chemical properties of used aluminous cement and FGCP.

\begin{tabular}{lcc}
\hline Chemical properties & Secar 71 & FGCP \\
\hline $\mathrm{Al}_{2} \mathrm{O}_{3}$ & $70.80 \%$ & $13.98 \%$ \\
$\mathrm{CaO}$ & $27.50 \%$ & $8.18 \%$ \\
$\mathrm{SiO}_{2}$ & $0.58 \%$ & $63.45 \%$ \\
$\mathrm{Fe}_{2} \mathrm{O}_{3}$ & $0.42 \%$ & $5.39 \%$ \\
$\mathrm{Na}_{2} \mathrm{O}$ & $0.27 \%$ & $0.90 \%$ \\
$\mathrm{MgO}$ & $0.21 \%$ & - \\
$\mathrm{K}_{2} \mathrm{O}$ & $0.06 \%$ & $2.43 \%$ \\
$\mathrm{TiO}_{2}$ & - & $0.77 \%$ \\
Specific surface area & $381 \mathrm{~m}^{2} \cdot \mathrm{kg}^{-1}$ & $336 \mathrm{~m}^{2} \cdot \mathrm{kg}^{-1}$ \\
\hline
\end{tabular}

Besides absolute values relative values [\%] are added related to the reference samples dried to $105^{\circ} \mathrm{C}$ for each mixture.

We can observe (Figure 4) the gradual decay of bulk density due to effect of high temperature, when physically bounded water is evaporated first. Increase of temperature leads to further decrease of bulk density which is caused by partial chemical decomposition of hydration products. Application of FGCP as aluminous cement replacement led to slight reduction of bulk density of heated and nonheated samples.

With increasing dose of basalt fibers the bulk density is getting down which is probably caused by air-entraining effect of extreme high amount of fibers, but it is very interesting that higher dose of basalt fibers reduces residual values too. Dose of $0.50 \%$ of basalt fibers seems to be optimal according to total and residual values of bulk density.

Flexural strength was essentially affected by the basalts fibers application. Increased amount of used fibers led to increase of flexural strength but not exactly according to their total dosage. Final values of flexural strength of mixtures with fibers application do not differ much (Figure 5). Final values in case of the lowest $(0.25 \%)$ and the highest (4.0\%) dosage are rather similar, so for such formulated mixtures the dosage of $4.0 \%$ in volume is economically limiting. It is probably caused by imperfect space distribution of used fibers in such formulated mixture composition with coarser aggregates which is well documented on the results of fracture energy determination described below. 
TABLE 3: Results of basic mechanical parameters measurement.

\begin{tabular}{|c|c|c|c|c|c|c|c|c|c|c|c|c|c|c|c|}
\hline \multirow[b]{3}{*}{ R-0 } & \multirow{3}{*}{\multicolumn{2}{|c|}{$\begin{array}{c}105^{\circ} \mathrm{C} \\
f_{\mathrm{tm}} \\
(\mathrm{MPa})\end{array}$}} & \multirow{3}{*}{$\begin{array}{c}\begin{array}{c}f_{\mathrm{cm}} \\
(\mathrm{MPa})\end{array} \\
47.7\end{array}$} & \multicolumn{6}{|c|}{$600^{\circ} \mathrm{C}$} & \multicolumn{6}{|c|}{$1000^{\circ} \mathrm{C}$} \\
\hline & & & & \multicolumn{2}{|c|}{$\begin{array}{c}\rho \\
\left(\mathrm{kg} \cdot \mathrm{m}^{-3}\right) /(\%)\end{array}$} & \multicolumn{2}{|c|}{$\begin{array}{c}f_{\mathrm{tm}} \\
(\mathrm{MPa}) /(\%)\end{array}$} & \multicolumn{2}{|c|}{$\begin{array}{c}f_{\mathrm{cm}} \\
(\mathrm{MPa}) /(\%)\end{array}$} & \multicolumn{2}{|c|}{$\begin{array}{c}\rho \\
\left(\mathrm{kg} \cdot \mathrm{m}^{-3}\right) /(\%)\end{array}$} & \multicolumn{2}{|c|}{$\underset{(\mathrm{MPa}) /(\%)}{f_{\mathrm{tm}}}$} & \multicolumn{2}{|c|}{$\begin{array}{c}f_{\mathrm{cm}} \\
(\mathrm{MPa}) /(\%)\end{array}$} \\
\hline & & & & 2260 & 97.0 & 2.1 & 40.4 & 31.1 & 65.2 & 2185 & 93.8 & 1.5 & 28.8 & 18.8 & 39.4 \\
\hline $\mathrm{R}-5$ & 2326 & 5.4 & 46.9 & 2216 & 95.3 & 4.2 & 77.8 & 39.4 & 84.0 & 2151 & 92.5 & 2.3 & 42.6 & 22.6 & 48.2 \\
\hline $\mathrm{R}-10$ & 2327 & 5.5 & 48.5 & 2250 & 96.7 & 3.8 & 69.1 & 40.5 & 83.5 & 2199 & 94.5 & 2.0 & 36.4 & 20.9 & 43.1 \\
\hline R-15 & 2320 & 6.7 & 50.3 & 2247 & 96.9 & 4.1 & 61.2 & 45.0 & 89.5 & 2195 & 94.6 & 2.2 & 32.8 & 21.5 & 42.7 \\
\hline R-20 & 2355 & 8.2 & 53.3 & 2258 & 95.9 & 5.0 & 61.0 & 49.2 & 92.3 & 2232 & 94.8 & 2.0 & 24.4 & 23.5 & 44.1 \\
\hline $\mathrm{R}-25$ & 2291 & 7.9 & 48.9 & 2201 & 96.1 & 4.4 & 55.7 & 41.2 & 84.3 & 2182 & 95.2 & 3.3 & 41.8 & 29.9 & 61.1 \\
\hline A-0 & 2280 & 13.2 & 113.5 & 2175 & 95.4 & 5.7 & 43.2 & 68.3 & 60.2 & 2130 & 93.4 & 3.4 & 25.8 & 27.1 & 23.9 \\
\hline$A-5$ & 2326 & 15.8 & 132.5 & 2164 & 93.0 & 6.5 & 41.1 & 74.2 & 56.0 & 2155 & 92.6 & 3.0 & 19.0 & 28.5 & 21.5 \\
\hline A-10 & 2370 & 16.7 & 133.0 & 2178 & 91.9 & 7.4 & 44.3 & 89.1 & 67.0 & 2167 & 91.4 & 4.3 & 25.7 & 37.7 & 28.3 \\
\hline A-15 & 2360 & 16.0 & 130.3 & 2189 & 92.8 & 8.6 & 53.8 & 87.0 & 66.8 & 2125 & 90.0 & 4.3 & 26.9 & 38.8 & 29.8 \\
\hline A-20 & 2340 & 15.1 & 126.0 & 2153 & 92.0 & 7.9 & 52.3 & 85.3 & 67.7 & 2135 & 91.2 & 4.8 & 31.8 & 37.8 & 30.0 \\
\hline A-25 & 2345 & 13.5 & 97.0 & 2140 & 91.3 & 6.5 & 48.1 & 62.6 & 64.5 & 2125 & 90.6 & 3.2 & 23.7 & 31.5 & 32.5 \\
\hline B-0 & 2440 & 11.9 & 100.5 & 2320 & 95.1 & 5.9 & 49.6 & 64.1 & 63.8 & 2270 & 93.0 & 3.7 & 31.1 & 36.2 & 36.0 \\
\hline B-5 & 2441 & 12.8 & 95.3 & 2320 & 95.0 & 6.3 & 49.2 & 63.6 & 66.7 & 2280 & 93.4 & 3.8 & 29.7 & 40.8 & 42.8 \\
\hline B-10 & 2425 & 13.1 & 91.7 & 2284 & 94.2 & 6.5 & 49.6 & 59.8 & 65.2 & 2255 & 93.0 & 3.6 & 27.5 & 39.6 & 43.2 \\
\hline B-15 & 2402 & 12.9 & 84.5 & 2238 & 93.2 & 5.8 & 45.0 & 56.2 & 66.5 & 2237 & 93.1 & 3.6 & 27.9 & 34.4 & 40.7 \\
\hline B-20 & 2342 & 12.5 & 82.1 & 2215 & 94.6 & 5.7 & 45.6 & 54.8 & 66.7 & 2205 & 94.2 & 3.4 & 27.2 & 35.1 & 42.8 \\
\hline B-25 & 2306 & 12.9 & 80.2 & 2135 & 92.6 & 6.1 & 47.3 & 52.0 & 64.8 & 2125 & 92.2 & 3.2 & 24.8 & 35.2 & 43.9 \\
\hline C-0 & 2250 & 13.4 & 93.9 & 2180 & 96.9 & 6.2 & 46.3 & 52.7 & 56.1 & 2120 & 96.4 & 3.7 & 27.6 & 26.4 & 28.1 \\
\hline C-5 & 2408 & 12.3 & 95.7 & 2275 & 94.5 & 5.8 & 47.2 & 55.9 & 58.4 & 2223 & 92.3 & 3.7 & 30.1 & 31.1 & 32.5 \\
\hline C-10 & 2415 & 12.0 & 98.7 & 2287 & 94.7 & 5.8 & 48.3 & 53.6 & 54.3 & 2217 & 91.8 & 3.9 & 32.5 & 32.3 & 32.7 \\
\hline C-15 & 2342 & 11.6 & 94.5 & 2225 & 95.0 & 6.0 & 51.7 & 51.4 & 54.4 & 2135 & 91.2 & 4.1 & 35.3 & 28.6 & 30.3 \\
\hline C-20 & 2312 & 11.2 & 92.1 & 2198 & 95.1 & 5.5 & 49.1 & 50.3 & 54.6 & 2108 & 91.2 & 4.0 & 35.7 & 28.1 & 30.5 \\
\hline C-25 & 2247 & 10.7 & 89.0 & 2104 & 93.6 & 5.0 & 46.7 & 48.7 & 54.7 & 2067 & 92.0 & 3.8 & 35.5 & 27.6 & 31.0 \\
\hline D-0 & 2400 & 12.3 & 94.1 & 2225 & 92.7 & 6.6 & 53.7 & 58.6 & 62.3 & 2210 & 92.1 & 3.8 & 30.9 & 29.8 & 31.7 \\
\hline D-5 & 2343 & 14.1 & 90.0 & 2196 & 93.7 & 7.1 & 50.4 & 55.1 & 61.2 & 2165 & 92.4 & 3.8 & 27.0 & 27.1 & 30.1 \\
\hline D-10 & 2332 & 13.9 & 93.2 & 2210 & 94.8 & 7.3 & 52.5 & 57.9 & 62.1 & 2151 & 92.2 & 3.7 & 26.6 & 29.5 & 31.7 \\
\hline D-15 & 2265 & 13.6 & 90.2 & 2138 & 94.4 & 6.9 & 50.7 & 54.6 & 60.5 & 2125 & 93.8 & 4.0 & 29.4 & 24.3 & 26.9 \\
\hline D-20 & 2264 & 13.4 & 97.9 & 2130 & 94.1 & 6.8 & 50.7 & 62.3 & 63.6 & 2095 & 92.5 & 4.2 & 31.3 & 32.4 & 33.1 \\
\hline D-25 & 2275 & 12.3 & 99.4 & 2120 & 93.2 & 6.9 & 56.1 & 64.4 & 64.8 & 2083 & 91.6 & 4.2 & 34.1 & 33.3 & 33.5 \\
\hline E-0 & 2186 & 18.0 & 99.1 & 2072 & 94.8 & 9.8 & 54.4 & 58.8 & 59.3 & 1954 & 89.4 & 3.9 & 21.7 & 21.1 & 21.3 \\
\hline E-5 & 2095 & 18.9 & 87.5 & 1940 & 92.6 & 7.7 & 40.7 & 42.8 & 48.9 & 1886 & 90.0 & 4.0 & 21.2 & 20.0 & 22.9 \\
\hline E-10 & 2064 & 19.3 & 82.4 & 1905 & 92.3 & 8.1 & 42.0 & 40.7 & 49.4 & 1845 & 89.4 & 4.2 & 21.8 & 22.4 & 27.2 \\
\hline E-15 & 2002 & 18.9 & 79.8 & 1898 & 94.8 & 8.5 & 45.0 & 39.7 & 49.7 & 1815 & 90.7 & 3.6 & 19.0 & 18.9 & 23.7 \\
\hline E-20 & 2005 & 18.3 & 78.4 & 1870 & 93.3 & 6.9 & 37.7 & 37.9 & 48.3 & 1810 & 90.3 & 4.1 & 22.4 & 20.8 & 26.5 \\
\hline E-25 & 1996 & 17.9 & 77.0 & 1840 & 92.2 & 6.5 & 36.3 & 35.4 & 46.0 & 1801 & 90.2 & 4.4 & 24.6 & 21.8 & 28.3 \\
\hline
\end{tabular}

Very interesting finding offers the evaluation of impact of FGCP replacement on studied composites in relation to flexural strength results which often pay for important material parameters. Residual values of flexural strength of each set of mixtures exhibit nearly similar results which well document great potential of studied additive for wider utilization. By comparison of relative values of flexural strength we can observe increasing stability of all studied mixtures.

Final values of compressive strength well correspond with flexural strength results. Application of basalt fibers increased total values of compressive strength but higher dose of basalt fiber led to reduction of this parameter, however, as well as in case of flexural strength seeming to be not effective (Figures 5 and 6). Objective of refractory composites is the evaluation of residual values which were in case of compressive strength positively affected by FGCP application. Increasing of mixture stability, marked on relative values, is more extensive in sets of mixture with lower dose of fibers. Generally final results of compressive strength are quite similar both in terms of ceramic powder replacement and in terms of basalt fibers application which is more optimistic predominantly for studied additive because of explicit savings.

Investigation of fracture properties serves usually to complement experimental program for better description of 


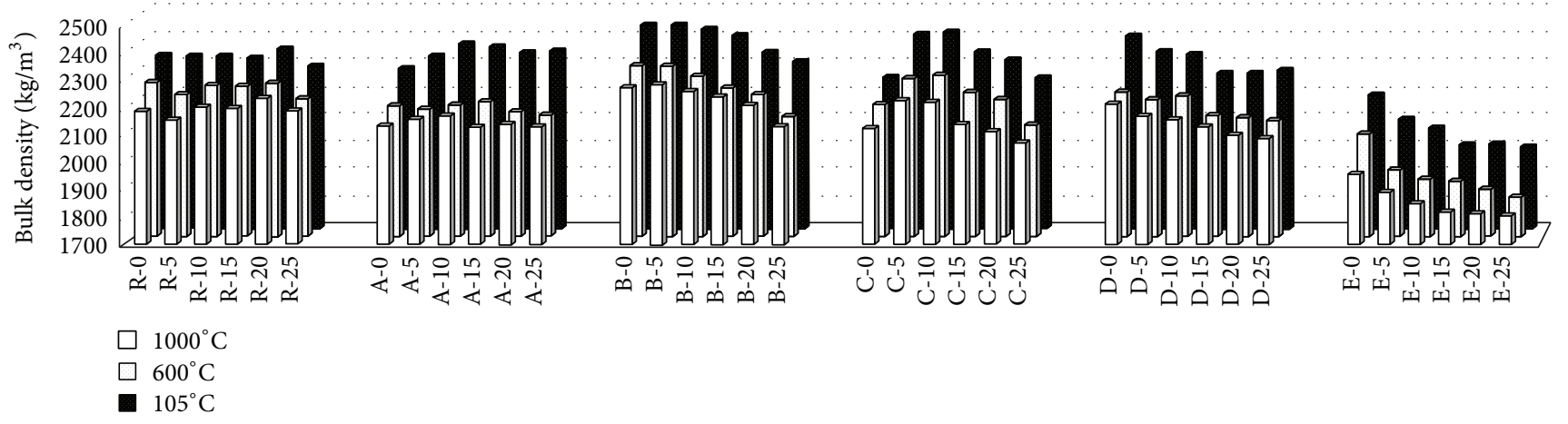

FIGURE 4: Impact of different composition and temperature loading on bulk density.

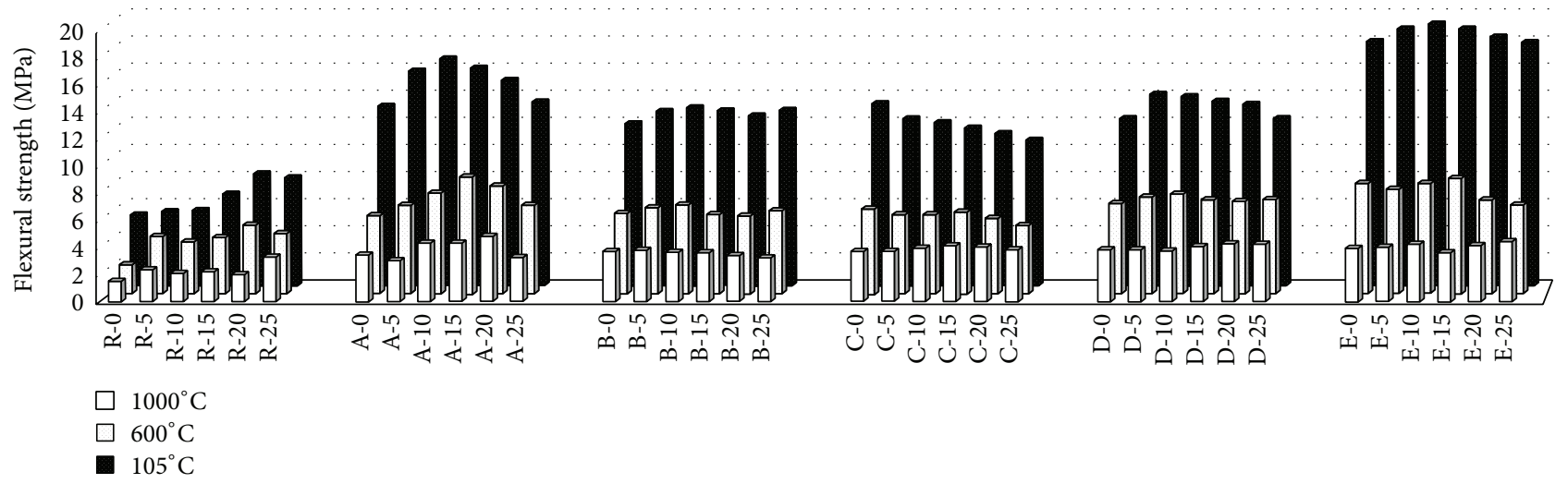

FIGURE 5: Impact of different composition and temperature loading on flexural strength.

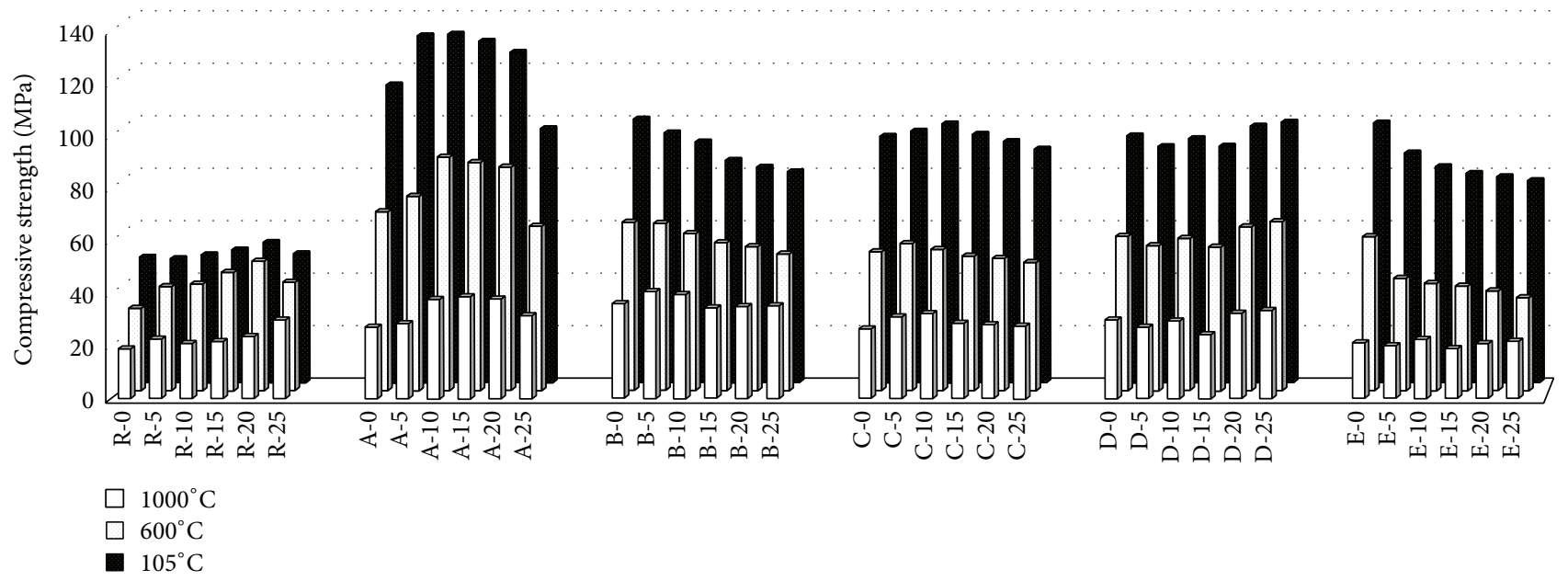

FIGURE 6: Impact of different composition and temperature loading on compressive strength.

ongoing changes because of extensive sensitiveness of present methodology. The fracture energy values reflect the failure mechanism and deformation properties of studied composites, and especially can describe the failure mode (fragile or soft) and the softening part of stress-strain diagram. Results of previous research [43] exhibited that, besides exact evaluation of composition changes, investigation of fracture energy could document the microstructural changes due to high temperature impact which is noticeable in Figure 7. Original brittle behavior of studied composites evinced apparent softening. Detailed results of fracture energy determination are shown in Table 4, a graphical illustration in Figure 8.

Determination of fracture energy brought valuable information about impact of different composition of studied mixtures which were not entirely obvious especially for fiber application. On the background of fracture energy results 
TABLE 4: Fracture energy of studied composites.

\begin{tabular}{|c|c|c|c|c|c|}
\hline \multirow{2}{*}{ Mixture } & \multirow{2}{*}{$\begin{array}{l}\text { Basalt fiber } \\
\text { volume (\%) }\end{array}$} & \multirow{2}{*}{$\begin{array}{c}\text { FGCP } \\
\text { replacement (\%) }\end{array}$} & \multicolumn{3}{|c|}{ Fracture energy $\left(\mathrm{J} \cdot \mathrm{m}^{-2}\right)$} \\
\hline & & & $105^{\circ} \mathrm{C}$ & $600^{\circ} \mathrm{C}$ & $1000^{\circ} \mathrm{C}$ \\
\hline $\mathrm{R}-0$ & \multirow{6}{*}{0} & 0 & 50.1 & 47.6 & 39.6 \\
\hline R-5 & & 5 & 65.8 & 60.4 & 52.3 \\
\hline $\mathrm{R}-10$ & & 10 & 68.4 & 63.5 & 58.6 \\
\hline R-15 & & 15 & 75.3 & 65.5 & 55.6 \\
\hline $\mathrm{R}-20$ & & 20 & 87.8 & 72.3 & 51.2 \\
\hline $\mathrm{R}-25$ & & 25 & 70.5 & 55.4 & 53.4 \\
\hline A-0 & \multirow{6}{*}{0.25} & 0 & 110.3 & 60.4 & 22.9 \\
\hline A-5 & & 5 & 135.9 & 68.7 & 52.9 \\
\hline A-10 & & 10 & 179.4 & 82.0 & 66.1 \\
\hline A-15 & & 15 & 209.2 & 93.9 & 70.7 \\
\hline A-20 & & 20 & 185.2 & 84.3 & 78.0 \\
\hline A-25 & & 25 & 160.4 & 79.3 & 77.9 \\
\hline B-0 & \multirow{6}{*}{0.50} & 0 & 275.5 & 128.3 & 82.5 \\
\hline B-5 & & 5 & 315.2 & 135.4 & 89.2 \\
\hline B-10 & & 10 & 302.4 & 142.8 & 95.6 \\
\hline B-15 & & 15 & 295.8 & 128.9 & 68.7 \\
\hline B-20 & & 20 & 281.5 & 117.4 & 72.5 \\
\hline B-25 & & 25 & 303.8 & 148.4 & 70.6 \\
\hline C-0 & \multirow{6}{*}{1.0} & 0 & 207.0 & 71.4 & 63.9 \\
\hline C-5 & & 5 & 218.6 & 112.6 & 68.7 \\
\hline C-10 & & 10 & 215.2 & 99.5 & 65.0 \\
\hline C-15 & & 15 & 216.0 & 86.9 & 61.2 \\
\hline C-20 & & 20 & 227.6 & 85.6 & 62.1 \\
\hline C-25 & & 25 & 238.8 & 94.7 & 72.9 \\
\hline D-0 & \multirow{6}{*}{2.0} & 0 & 127.2 & 94.3 & 57.0 \\
\hline D-5 & & 5 & 182.7 & 109.5 & 63.9 \\
\hline D-10 & & 10 & 179.9 & 118.2 & 72.5 \\
\hline D-15 & & 15 & 165.8 & 121.8 & 64.2 \\
\hline D-20 & & 20 & 142.3 & 95.4 & 58.9 \\
\hline D-25 & & 25 & 133.4 & 89.4 & 67.3 \\
\hline E-0 & \multirow{6}{*}{4.0} & 0 & 115.2 & 81.0 & 64.0 \\
\hline E-5 & & 5 & 121.6 & 75.5 & 72.4 \\
\hline E-10 & & 10 & 132.1 & 68.5 & 65.8 \\
\hline E-15 & & 15 & 125.5 & 57.4 & 52.8 \\
\hline E-20 & & 20 & 102.3 & 62.3 & 60.0 \\
\hline E-25 & & 25 & 99.7 & 59.7 & 52.6 \\
\hline
\end{tabular}

we can well compare efficiency of fiber employment under testing.

Dose of $0.50 \%$ of basalt fibers is considerably the best variation of applied amount of fibers which is not closely in compliance with flexural and compressive strength results. On the other side, the set of mixtures with $0.50 \%$ of basalt fibers exhibited the biggest decay of fracture energy due to temperature loading; nevertheless they are still slightly higher than other investigated mixtures. Residual values of fracture energy after loading up to $600^{\circ} \mathrm{C}$ are about $10 \%$ higher as well as for $1000^{\circ} \mathrm{C}$ temperature load.

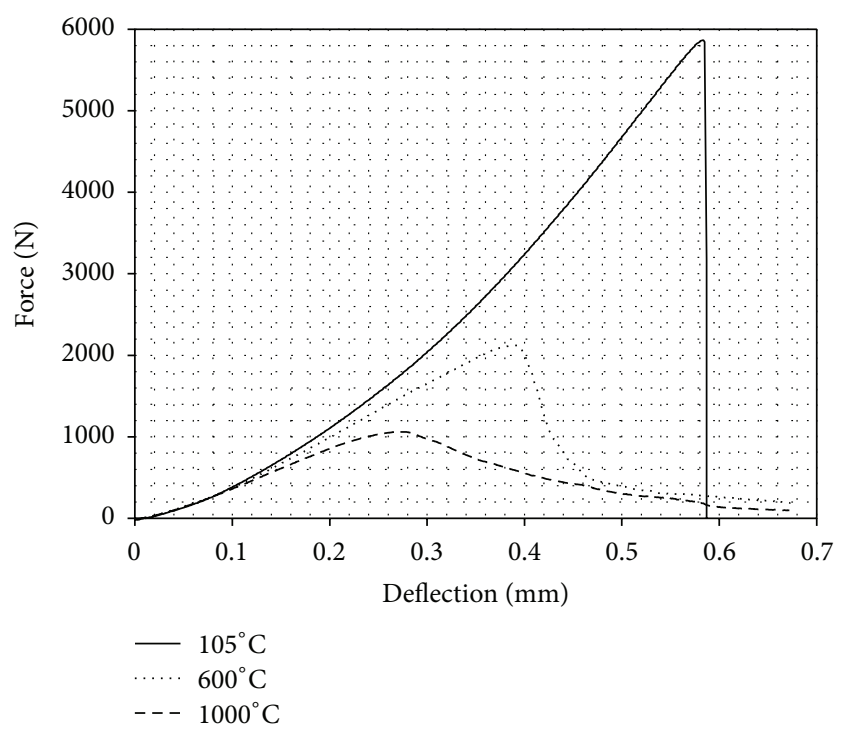

Figure 7: Changes of mechanical behaviour due to temperature loading (example).

Optimal space distribution of fibers contributed partially to residual resistance. It has an essential sense for mixture composition optimization and for increasing of economical parameters of developed composites. Decrease of fracture properties of sets of mixtures "C", "D," and "E" (1.0, 2.0, and $4.0 \%$ of basalt fibers) was caused by deficient of cohesiveness of used fibers and binder matrix which was powered by line distribution of fibers. Then during loading they were not adequately bonded and slipped out the structure.

Investigation of fracture energy confirmed results of basic mechanical test given to FGCP application. Binder matrix modified by addition of FGCP exhibited sufficient bond properties. For mixtures with lower content of basalt fibers $(0.25$ and $0.50 \%)$ values of fracture energy are getting higher with FGCP dosage as well as for mixtures without fibers. Because content of silica in FGCP is the general contribution of studied additive to residual properties noticeable particularly for composites loaded up to $600^{\circ} \mathrm{C}$, influencing of residual values of fracture properties after $1000^{\circ} \mathrm{C}$ is quite similar for all sets of mixtures.

\section{Conclusion}

Residual properties of high temperature resistant composites with different composition were investigated in performed experimental program. Attention was paid to determination of influence of basalt fibers dose and to study of FGCP as aluminous cement replacement. The motivation was to develop high temperature resistant fiber-reinforced composite with reduced environmental impact. Basic physical, mechanical, and fracture properties before and after temperature loading were measured in order to evaluate the system behaviour.

The most suitable and economic option is $10 \%$ replacement of aluminous cement by FGCP and application of basalt fibers dose $0.25 \%$ in volume in terms of all investigated 


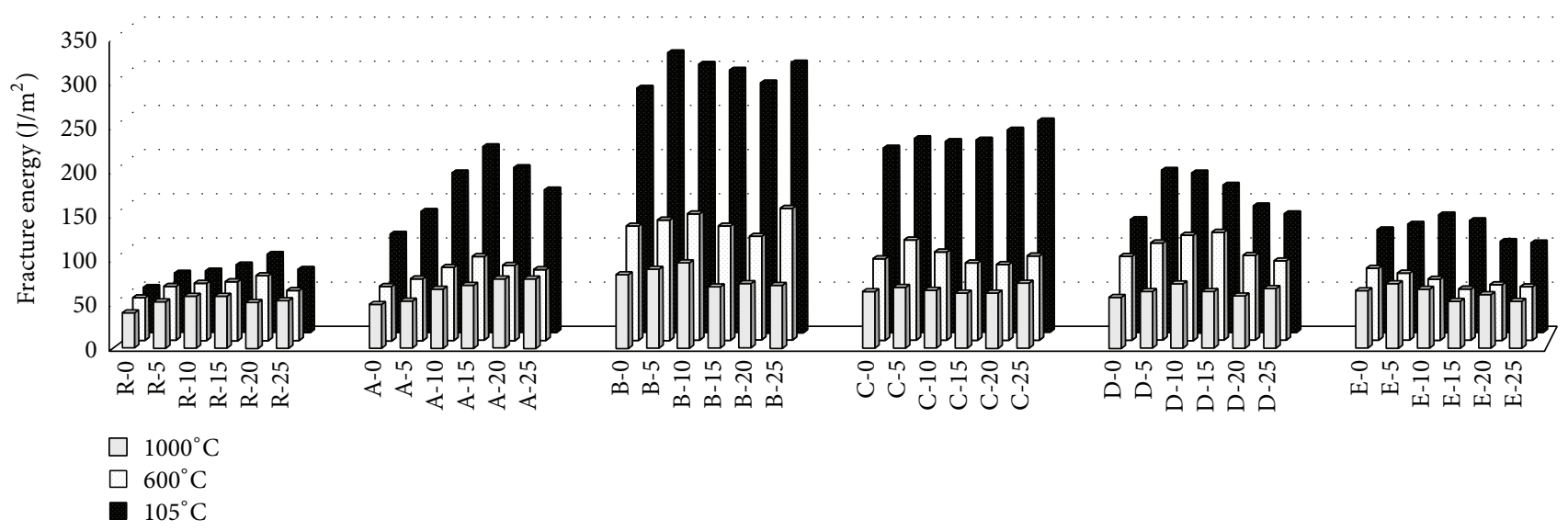

FIGURE 8: Impact of different composition and temperature loading on fracture energy.

residual parameters after exposure to $1000^{\circ} \mathrm{C}$. Increased dose of basalt fibers did not exhibit increasing flexural and compressive strength as well as fracture energy which was probably caused by defective spatial distribution of fibers.

Application of FGCP as a cement supplementary material seems to be very effective. FGCP significantly contributes to keeping the stability of all studied properties after high temperature loading which was declared on the results of studied residual properties measurement in comparison to reference mixtures. There is an expressive environmental benefit too with respect to economic aspects of used high aluminous cement and mentioned additive.

\section{Conflict of Interests}

The authors declare that there is no conflict of interests.

\section{Acknowledgments}

This research work was financially supported by Czech Science Foundation over Project no. P104/12/0791 which is gratefully acknowledged. The authors appreciate the assistance given by employees of Experimental Centre of Faculty of Civil Engineering, Czech Technical University in Prague.

\section{References}

[1] R. Černý, J. Poděbradská, J. Toman et al., "High temperature properties of fibre reinforced cement composites," in Proceedings of the International Conference on Application of Codes, Design and Regulations, pp. 403-412, July 2005.

[2] Y. Fu and L. Li, "Study on mechanism of thermal spalling in concrete exposed to elevated temperatures," Materials and Structures, vol. 44, no. 1, pp. 361-376, 2011.

[3] Y. B. Jiao, H. B. Liu, X. Q. Wang, Y. W. Zhang, G. B. Luo, and Y. F. Gong, "Temperature effect on mechanical properties and damage identification of concrete structure," Advances in Materials Science and Engineering, vol. 2014, Article ID 191360, 10 pages, 2014.
[4] E. Vejmelková and R. Černý, "Thermal properties of PVA-Fiber reinforced cement composites at high temperatures," Applied Mechanics and Materials, vol. 377, pp. 45-49, 2013.

[5] Z. J. Li, X. M. Zhou, and B. Shen, "Fiber-cement extrudates with perlite subjected to high temperatures," Journal of Materials in Civil Engineering, vol. 16, no. 3, pp. 221-229, 2004.

[6] A. M. Neville, Properties of Concrete, Prentice Hall, 5th edition, 2012.

[7] E. Vejmelková, P. Konvalinka, P. Padevět, and R. Černý, "Thermophysical and mechanical properties of fiber-reinforced composite material subjected to high temperatures," Journal of Civil Engineering and Management, vol. 16, no. 3, pp. 395-400, 2010.

[8] C. Jiang, K. Fan, F. Wu, and D. Chen, "Experimental study on the mechanical properties and microstructure of chopped basalt fibre reinforced concrete," Materials and Design, vol. 58, pp. 187193, 2014.

[9] P. Banibayat and A. Patnaik, "Variability of mechanical properties of basalt fiber reinforced polymer bars manufactured by wet-layup method," Materials and Design, vol. 56, pp. 898-906, 2014.

[10] Y. Ma, T. Sugahara, Y. Yang, and H. Hamada, "A study on the energy absorption properties of carbon/aramid fiber filament winding composite tube," Composite Structures, vol. 123, pp. 301-311, 2015.

[11] V. Slivka and M. Vavro, "The significance of textural and structural properties of north-moravian basaltoids for the manufacture of mineral fibres," Ceramics, vol. 40, no. 4, pp. 149 159, 1996.

[12] T. Jung and R. V. Subramanian, "Strengthening of basalt fiber by alumina addition," Scripta Metallurgica et Materiala, vol. 28, no. 4, pp. 527-532, 1993.

[13] B. Perevozchikova, A. Pisciotta, B. Osovetsky, E. Menshikov, and K. Kazymov, "Quality evaluation of the kuluevskaya basalt outcrop for the production of mineral fiber, Southern Urals, Russia," Energy Procedia, vol. 59, pp. 309-314, 2014.

[14] S. I. Gutnikov, M. S. Manylov, Y. V. Lipatov, B. I. Lazoryak, and K. V. Pokholok, "Effect of the reduction treatment on the basalt continuous fiber crystallization properties," Journal of Non-Crystalline Solids, vol. 368, no. 1, pp. 45-50, 2013.

[15] M. Mateo, C. Pérez-Carramiñana, and S. Chinchón, "Varieties of asbestos in buildings and risks associated with the work of 
deconstruction," Informes de la Construccion, vol. 65, no. 531, pp. 311-324, 2013.

[16] G. Landucci, F. Rossi, C. Nicolella, and S. Zanelli, "Design and testing of innovative materials for passive fire protection," Fire Safety Journal, vol. 44, no. 8, pp. 1103-1109, 2009.

[17] V. Dhand, G. Mittal, K. Y. Rhee, S. Park, and D. Hui, "A short review on basalt fiber reinforced polymer composites," Composites Part B: Engineering, vol. 73, pp. 166-180, 2015.

[18] M. Jogl, P. Reiterman, O. Holčapek, and J. Kot'átková, "Effects of high temperature treatment on the mechanical properties of basalt fiber reinforced aluminous composites," Applied Mechanics and Materials, vol. 732, pp. 111-114, 2015.

[19] V. A. Rybin, A. V. Utkin, and N. I. Baklanova, "Alkali resistance, microstructural and mechanical performance of zirconiacoated basalt fibers," Cement and Concrete Research, vol. 53, pp. 1-8, 2013.

[20] S. Baştürk, H. Uyanık, and Z. Kazancı, "An analytical model for predicting the deflection of laminated basalt composite plates under dynamic loads," Composite Structures, vol. 116, pp. 273285, 2014.

[21] J. Krassowska and A. Lapko, "The influence of basalt fibers on the shear and flexural capacity of reinforced concrete continuous beams," in Proceedings of the 1st International Conference for Ph.D. Students in Civil Engineering (CE-PhD '12), Cluj-Napoca, Romania, November 2012.

[22] P. K. Mehta and P. J. Monteiro, Concrete: Microstructure, Properties, and Materials, 2006.

[23] P. C. Hewlett, Ed., Lea's Chemistry of Cement and Concrete, Elsevier, Oxford, UK, 4th edition, 2004.

[24] O. Holčapek, P. Reiterman, F. Vogel, E. Vejmelková, and P. Konvalinka, "Mechanical properties of aluminous paste at high temperature," in Research and Applications in Structure Engineering, Mechanics and Computation, CRC Press, Leiden, The Netherlands, Balkema, Cape Town, South Africa, 2013.

[25] T. M. Kula, M. D. Meiser, and R. E. Tressler, "Curing temperature and humidity effects on the strength of an aluminous cement," Cement and Concrete Research, vol. 10, no. 4, pp. 491497, 1980.

[26] G. A. Khoury, "Effect of fire on concrete and concrete structures," Progress in Structural Engineering and Materials, vol. 2, no. 4, pp. 429-447, 2000.

[27] E. Vejmelková, M. Keppert, P. Rovnaníková, M. Ondráček, Z. Keršner, and R. Černý, "Properties of high performance concrete containing fine-ground ceramics as supplementary cementitious material," Cement and Concrete Composites, vol. 34, no. 1, pp. 55-61, 2012.

[28] M. Drdácký, F. Fratini, D. Frankeová, and Z. Slížková, “The Roman mortars used in the construction of the Ponte di Augusto (Narni, Italy) - a comprehensive assessment," Construction and Building Materials, vol. 38, pp. 1117-1128, 2013.

[29] M. D. Jackson, E. N. Landis, P. F. Brune et al., "Mechanical resilience and cementitious processes in Imperial Roman architectural mortar," Proceedings of the National Academy of Sciences of the United States of America, vol. 111, no. 52, pp. 18484-18489, 2014.

[30] E. Vejmelková, M. Keppert, P. Rovnaníková, Z. Keršner, and R. Černý, "Properties of lime composites containing a new type of pozzolana for the improvement of strength and durability," Composites Part B: Engineering, vol. 43, no. 8, pp. 3534-3540, 2012.
[31] L. Bodnárová, T. Jarolim, J. Válek, J. Brožovský, and R. Hela, "Selected properties of cementitous composites with Portland cements and blended Portland cements in extreme conditions," Applied Mechanics and Materials, vol. 507, pp. 443-448, 2014.

[32] J. M. R. Mercury, A. H. de Aza, X. Turrillas, and P. Pena, "Calcium aluminate cements hydration. Part II: effect of silica and alumina additions," Boletín de la Sociedad Española de Cerámica y Vidrio, vol. 42, no. 6, pp. 361-368, 2003.

[33] A. H. López, J. L. G. Calvo, J. G. Olmo, S. Petit, and M. C. Alonso, "Microstructural evolution of calcium aluminate cements hydration with silica fume and fly ash additions by scanning electron microscopy, and mid and near-infrared spectroscopy," Journal of the American Ceramic Society, vol. 91, no. 4, pp. 1258-1265, 2008.

[34] E. Breval, " $\mathrm{C}_{3} \mathrm{~A}$ hydration," Cement and Concrete Research, vol. 6, no. 1, pp. 129-137, 1976.

[35] L. Fernández-Carrasco, M. T. Blanco-Varela, F. Puertas, T. Vázquez, F. P. Glasser, and E. Lachowski, "Hydration of high alumina cement in the presence of alkalis," Advances in Cement Research, vol. 12, no. 4, pp. 143-152, 2000.

[36] B. Pacewska, M. Nowacka, I. Wilińska, W. Kubissa, and V. Antonovich, "Studies on the influence of spent FCC catalyst on hydration of calcium aluminate cements at ambient temperature," Journal of Thermal Analysis and Calorimetry, vol. 105, no. 1, pp. 129-140, 2011.

[37] M. Cyr, M. Trinh, B. Husson, and G. Casaux-Ginestet, "Effect of cement type on metakaolin efficiency," Cement and Concrete Research, vol. 64, pp. 63-72, 2014.

[38] J. Ding, Y. Fu, and J. J. Beaudoin, "Strätlingite formation in high alumina cement-silica fume systems: Significance of sodium ions," Cement and Concrete Research, vol. 25, no. 6, pp. 1311-1319, 1995.

[39] M. Jogl, P. Reiterman, O. Holčapek, and J. Kot’átková, “Influence of high-temperature on polycarboxylate superplasticizer in aluminous cement based fibre composites," Advanced Materials Research, vol. 982, pp. 125-129, 2014.

[40] Czech Standard CSN EN 196-1 Methods of testing cement-Part 1: Determination of strength, 2005.

[41] N. Kabay, "Abrasion resistance and fracture energy of concretes with basalt fiber," Construction and Building Materials, vol. 50, pp. 95-101, 2014.

[42] RILEM, "Determination of the fracture energy of mortars and concrete by means of free-point bend test on notched beams," Materials and Structures, vol. 18, no. 106, pp. 285-290, 1985.

[43] O. Holčapek, P. Reiterman, and P. Konvalinka, "Fracture characteristics of refractory composites containing metakaolin and ceramic fibers," Advances in Mechanical Engineering, vol. 7, no. 3, pp. 1-13, 2015. 

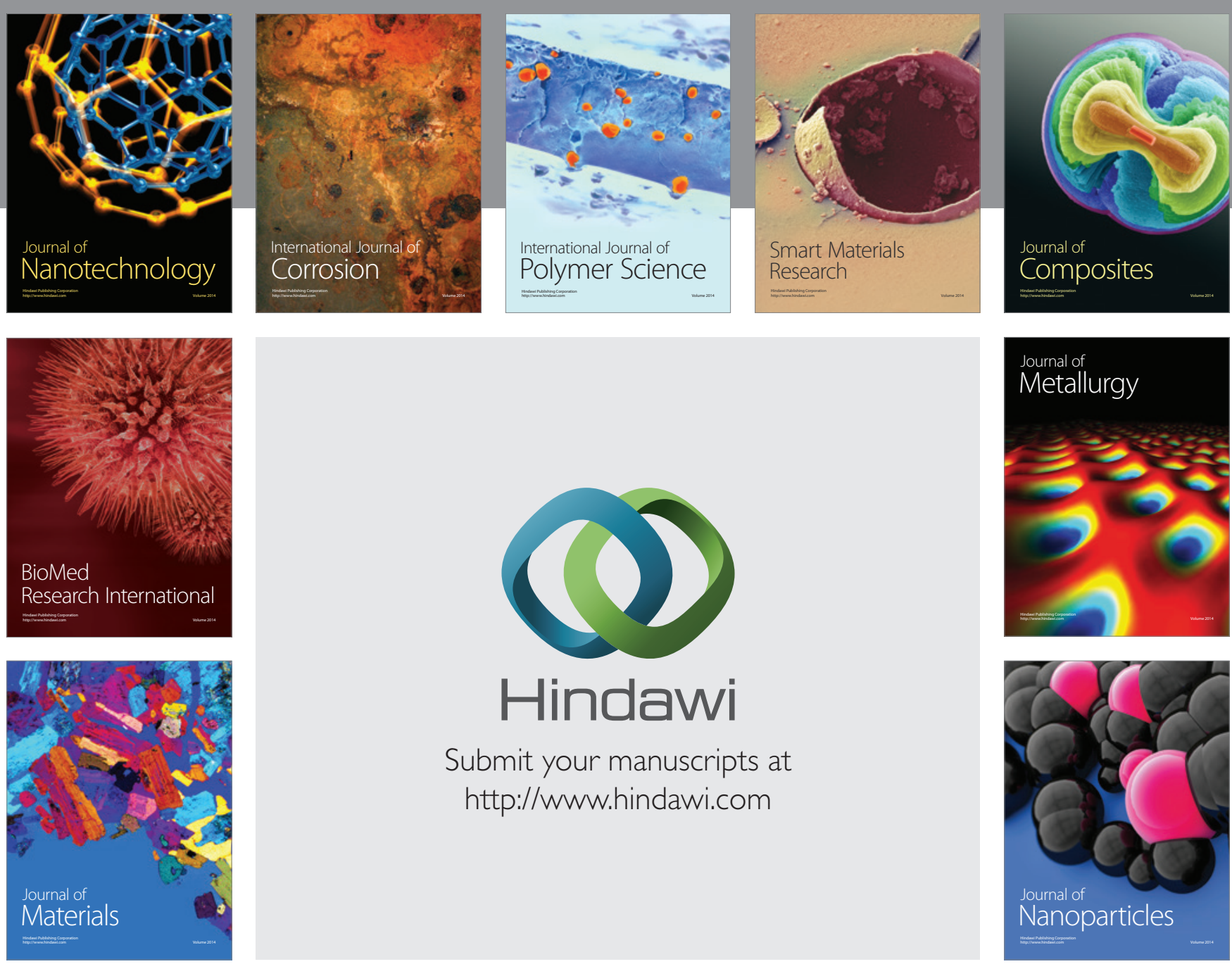

Submit your manuscripts at http://www.hindawi.com
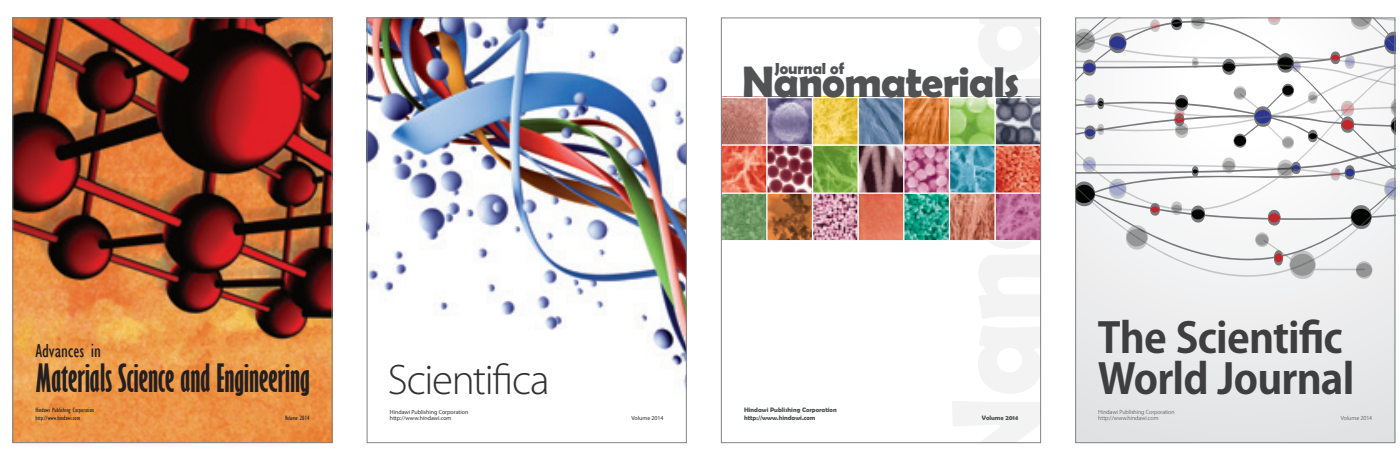

\section{The Scientific World Journal}
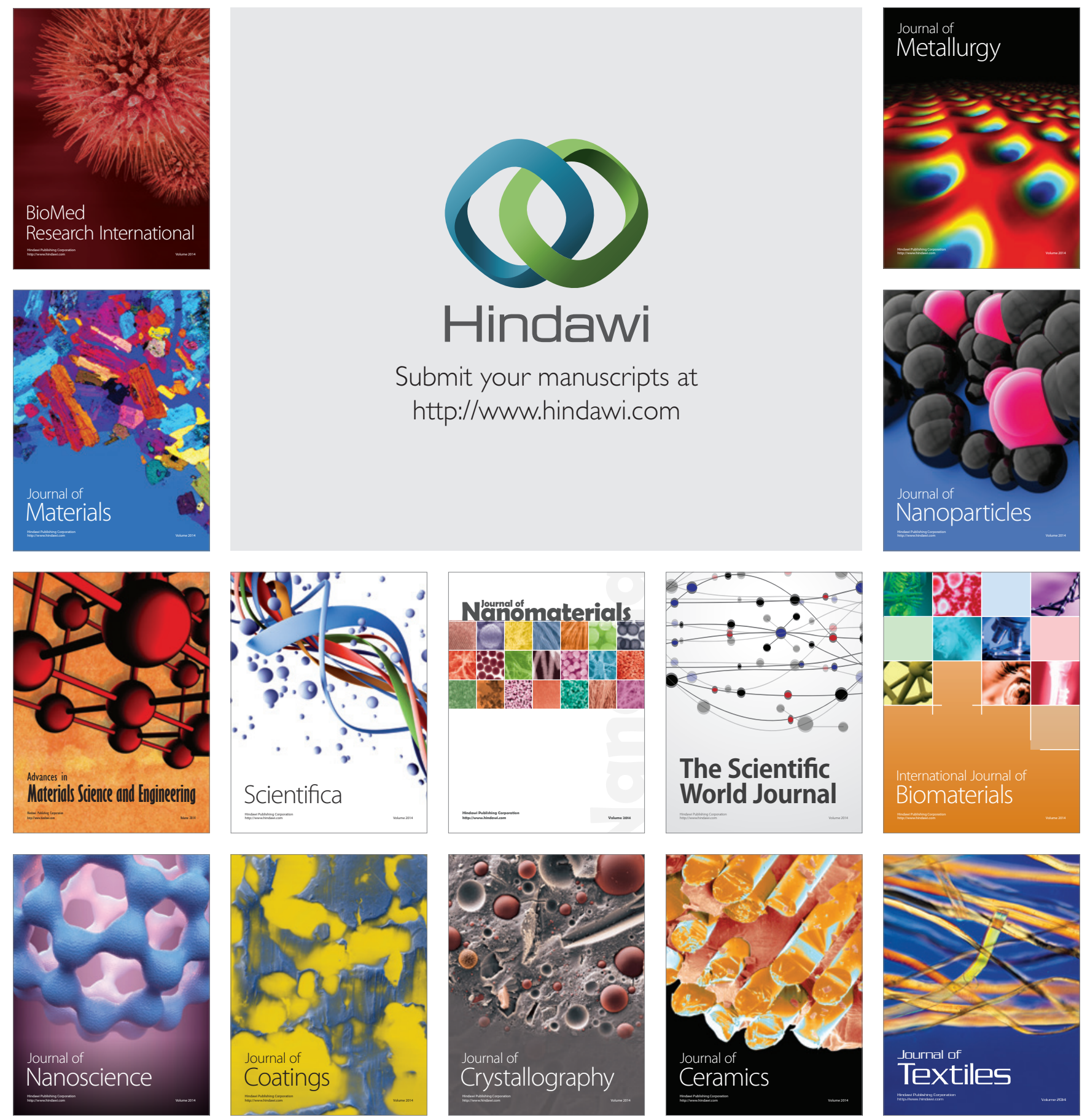